ment and government. It must be apparent also that in this work, their lack of the tact and talent of the poet will, more than elsewhere, hinder them from saying what they would like to say.

MAICOLM SHARP*

\title{
CONTRIBUTIONS OF THE SCIENCES OF MAN TO KEEPING THE PEACE
}

$D^{2}$ R. WEST, Dean Katz, and Mr. Sharp all are concerned with the conscious and unconscious hostilities of individuals, since groups and nations are complexes of private citizens, and the mass aggressiveness which leads to international conflict and lawlessness results from the compounded needs of the constituent members of such groups. Each writer refers to the new discoveries of clinical psychiatry and psychology which confirm the presence of aggressive drives in each human personality. Whether these tendencies, which certain theologians have included under the doctrine of "original sin," are the product of nature, of nurture, or of both is still undecided, but their origin is not the matter of primary concern. They are present in each person, to defend him from external attacks which would destroy him, to give him the initiative and enterprise to enter upon new activities, and unfortunately also to cause conflict with others who are competing for something he wants. One may not be aware of his hostilities-frequently he is not-but that does not mean they are not present. As the kindly old Quakeress said when she was complimented on her humble gentleness, "But thee wottest not how I do boil within."

Frequently it is terrifying to lawmakers, who have cast their lot on the side of reason, that these drives are often irrational. They are not by any means always dedicated to the best interests of the individual or his group. Just as an injection into the bloodstream of dead bacteria that can do no harm will result in a fever which is an immunity reaction, a purposeless activation of bodily defenses, so frequently a person's frustrations will mobilize his hostilities in ways not profitable to him or to anyone else. Aggression is a defense against the frustrations which daily beset each of us. Fighting back and restriving after failure is a necessary method of psychological defense, but hostility is irrational and pathological (just like the body's reaction to killed bacteria), when frustration arouses that particular defense mechanism to no purpose. And frustration nearly always does beget hostility, whether it be in the person who is not paid the salary he wants, in the race which is kept from the social recognition it desires, or in the nation which is blocked from its goal of world domination. The

* Professor of Law, University of Chicago Law School. 
recognition of these facts is one of the important new developments in the sciences of man.

Fortunately these disciplines are also developing the first glimmerings of hope for control of such aggression. Individual and group psychotherapy are being intensively studied by psychiatrists and psychologists. One of the primary concerns in this field is the understanding and modification of hostile desires. The techniques for doing this are as yet feeble, but it has already become clear that enmity can be both conscious and unconscious (so hidden from awareness that the individual knows absolutely nothing about its existence or how it affects his behavior or attitudes). Whether the law can require a person to be responsible for such processes is a difficult problem. And it is also extremely difficult for the psychotherapist to bring these types of aggressive instincts to the patient's awareness or to affect their operation and control them while they remain unconscious.

Our present confusion and uncertainty concerning such matters indicate that the sciences of man are far behind the physical sciences in their development. There is a distinct possibility that before man comes to understand, predict, and control his own behavior he will have created the physical instruments which will, despite him, destroy his civilization or his race. Yet in a time when policy-makers are beginning to recognize that the sciences of man should properly be the bases for the making of their decisions, those fields of study still can make only the most paltry contributions in the crisis.

The situation is not wholly without hope, however. New theories are being propounded, grounded in the careful observations of clinicians and scientists, such as those concerning the unconscious nature of many hostile impulses and the role of frustration in their genesis. Besides theory, new techniques are also developing. There is public opinion polling, for example -a promising method for measuring the attitudes of the masses even despite the recent election debacle which demonstrated that such procedures are ineffective unless they are applied with great technical care. The possession of methods for measuring attitudes makes possible scientific study of how attitudes arise and what their determinants are. Once these facts are known, we have important bases for managing human group behavior, since attitudes are so frequently the precursors of action. This is not a new idea to the lawyer, who has long been concerned with the relation of intent to action. It is the opportunity for precise measurement and accurate prediction that is new.

Another procedure of the sciences of man relevant to the problem of war 
and peace is the investigation of the genesis of class structure. Intergroup rivalries between those who consider themselves members of different classes or organizations lead to our bitterest conflicts. We are beginning to have methods of investigating the development of these interclass differentiations. Religious, racial, ideological, educational, political, and other such distinctions are the terms in which man rationalizes his hostilities and the banners under which he fights his wars. Intensive studies are now being made of the causes for such loyalties to groups and feelings of foreignness to others which precede overt attacks.

A closely related problem that concerns social scientists at present is the matter of barriers to communication. Many sorts of circumstances can keep facts and opinions from being accurately recorded or widely disseminated. Among these are barriers of language and racial, socioeconomic, or religious distinctions. Differences in prestige or rank of individuals, groups, and countries may also prevent complete and free interchange of information. Or blocked communication can occur when strong subgroups organize with powerful ingroup feeling so that they do not communicate their thoughts and feelings to others. This is one of the great dangers of nationalism which has since the beginning of history lowered iron curtains between nations. Sociologists and others, working usually with small communities, have studied mechanisms for improving communication which lead to the effective free flow of information. It is possible that these principles can also be applied to international problems.

Another issue faced by the scientists who study man has been how he comes to decisions. It has become apparent that many of the determinants of policy judgments lie in the backgrounds, educations, environmental influences, and heredities of those who make the decisions. It is also evident that group decisions, if the size of the group is limited, are frequently more correct that those of individuals. Researches are going on at the present time to study how committees operate-the committees that throughout the world from the Security Council of the United Nations on down are the instruments of policy. Perhaps these researches can outline procedures to take account of individual intellectual and emotional biases and advance the group productivity of such decision-making bodies.

Another area of rapid progress is in methods for the selection of leaders. We know that persons differ in the amount of uncontrolled hostility they have. We know certain reasons why some cannot keep their aggressions in check. One, for example, often seen in a leader who has risen from the masses to a position of power, is the development of the habit of striv- 
ing upward for continually greater personal recognition-a habit so potent that, when he achieves real power, he is still unsatisfied and must continue to fight for fame. Even if he has achieved all that he can demand in his lifetime, he may have the ineradicable pattern of battle in his personality. Frequently the peoples who are led by such a vainglorious man find themselves the dupes of his ambitions. There is real promise in the area of research in the choice of public executives who will be able to serve the peoples rather than have the peoples serve them and their unsatisfied hostile drives.

All these techniques are just now burgeoning into promise. Research is essential, research on many cases with careful evaluation of multiple variables. Psychological clinicians and psychiatrists can learn suggestive facts from the study of a single case, as can the lawyer, but scientific principles cannot be derived from one case. They are generalizations, and so can be confirmed only from the systematic study of many. This is an expensive and time-consuming process. Particularly in the complicated areas of the sciences of man it is expensive. However, knowledge of such facts about individual and group human nature and the interactions of men is essential as the "pre-clinical" science on which the practice of the lawyers and policy-makers in national and international scenes must be founded. Only with it can they devise procedures, regulations, sanctions, and controls which can establish a tradition of peace after the orgies of hostility that fill all the past chapters of history. There is hope for peace, but it will receive solid foundation only if public leaders, recognizing their desperate need for objective understanding of human behavior, do all they can to back the sciences of man so that those disciplines in turn can answer the crucial questions about the nature of humanity to which there is as yet no reply except an echo in the vastness of our ignorance.

JaMes G. MTLLeR, M.D.*

* Chairman, Department of Psychology, University of Chicago. 